\title{
An in vitro Model for the Effects of Estrogen on Neurons Employing Estrogen Receptor-transfected PC12 Cells
}

\author{
Robert H. Lustig,, ${ }^{1}$ Ping Hua, ${ }^{1}$ Wenqian Yu, ${ }^{2}$ Fridoon J. Ahmad, ${ }^{2}$ and Peter W. Baas ${ }^{2}$ \\ Departments of 'Pediatrics and ${ }^{2}$ Anatomy, University of Wisconsin, Madison, Wisconsin 53792
}

\begin{abstract}
Estrogen alters neurite outgrowth, neuritic spine development, and synaptogenesis in estrogen-responsive areas of the rat brain. However, examination of the specific effects of estrogen on neurons in vivo has been difficult. An in vitro model for the effects of estrogen on neurons was developed, using the PC12 rat pheochromocytoma cell line. Wild-type cells (PC12-WT) were stably transfected either with an expression vector coding for the full-length cDNA for the human estrogen receptor (hER), or with a control vector. Resultant clones were isolated, screened for incorporation of vector and expression of ER mRNA and protein, and analyzed for morphologic responses to estrogen.
\end{abstract}

PC12-WT, NEO9 (ER-negative), and SER8 (ER-positive) cells exposed to $100 \mathrm{ng} / \mathrm{ml}$ NGF exhibited dose-responsive neurite outgrowth within $2 \mathrm{~d}$ by light microscopy (LM). Coadministration of $10^{-10}$ to $10^{-9} \mathrm{M}$ estradiol $\left(E_{2}\right)$ had minimal effects on neurite outgrowth, neuritic spine development, or interneuritic connections in NEO9 or PC12-WT cells, but in SER8 cells $E_{2}$ led to additive and dose-dependent increases in neurite outgrowth, spine development, and interneuritic connectivity. Coincubation of SER8 cells with $E_{2}$ and the antiestrogen $\mathrm{ICI} 164,384$ negated estrogenic effects on spine development and interneuritic connectivity. At the electron microscopic (EM) level, intercellular abutments of NEO9 or PC12-WT cells contained few and rudimentary gap junctions, with no increase by $E_{2}$. However, SER8 cells exhibited augmented basal frequencies of gap junctions that increased with $E_{2}$ incubation. Microinjection of Lucifer yellow into PC12-WT and NEO9 cells demonstrated low frequencies of dye coupling and no change with $E_{2}$, but SER8 cells demonstrated increased dye-coupling frequency with $E_{2}$ coincubation.

The results suggest that SER8 cells recapitulate estrogen effects on neurons in vivo. Estrogen appears to induce an

\footnotetext{
Received Sept. 16, 1993; revised Dec. 27, 1993; accepted Jan. 4, 1994.

This work was presented in part at the 20th Meeting of the Society for Neuruscience, Waslinglon, D.C., 1993. We thank Drs. Bruce S. McEwen and C. Dominque Toran-Allerand for advice in formulating this project, Dr. V. Craig Jordan for the expression vectors, Dr. Howard J. Federoff for his continued scientific support and his gift of the wild-type PC12 cell line, Drs. Miles L. Epstein and Laurence $\mathrm{O}$. Trussell for helpful discussions, and Lu Ting-Yun, Shirley Keller, John Pink, Todd Thompson, and Xuan Thy Tran for technical advice, assistance, and expertise. This work was funded in part by Shannon Award R55 CA58044, National Institutes of Health (to R.H.L.), Grant NS 28785, National Institutes of Health (to P.W.B.), and Grant IBN-9209939, National Science Foundation (to P.W.B.). P.W.B. is the recipient of a Research Career Development Award from the National Institutes of Health.

Correspondence should be addressed to Dr. Robert Lustig, Department of Pediatrics, H4/476 CSC, University of Wisconsin Hospital, 600 Highland Avenue, Madison, WI 53792-4108.

Copyright (C) 1994 Society for Neuroscience $0270-6474 / 94 / 143945-13 \$ 05.00 / 0$
}

inherent neural morphologic program in estrogen receptor (ER)-containing cells. These three cell lines provide a unique in vitro system for studying mechanisms of estrogen-neuron interactions.

[Key words: estrogen, neurite outgrowth, spines, PC12 cells, gap junctions, sex dimorphisms]

Adult male and female rat brains differ in several biochemical and behavioral parameters (MacLusky and Naftolin, 1981; Arnold and Gorski, 1984; Gorski, 1984; Breedlove, 1992). This is evidenced by sex differences in response to estrogen. The ability of estrogen to activate changes in brain function is clearly sex specific (McEwen, 1983; McEwen et al., 1984), including alterations in neurotransmitter receptors (Fischette et al., 1983; Luine and McEwen, 1983), estrogen receptors (Lauber et al., 1991), progestin receptors (Rainbow et al., 1982), neuropeptide transcription (Romano et al., 1990), and gonadotropin-releasing hormone secretion, vis-à-vis the LH surge (Goodman, 1978; Corbier, 1985).

The above dimorphisms have neuroanatomic correlates. In the male rat, the cortical mantle of the left hemisphere is thinner than on the right, and than that noted in the female (Diamond et al., 1981; McShane et al., 1988). On a synaptic level, sex differences have been noted in the pattern of neuronal connectivity in the preoptic area (Raisman and Field, 1973; Fischette et al., 1983), arcuate nucleus (Matsumoto and Arai, 1980), and amygdala (Nishizuka and Arai, 1981). Most notable is the sex difference in the "sexually dimorphic nucleus" (SDN), a region of the medial preoptic area that is several times larger in males due to increased neuron number (Gorski et al., 1980; Jacobson et al., 1981; Döhler et al., 1986) and also exhibits greater neuritic growth and extent (Hammer and Jacobson, 1984). These sexdependent alterations in neurite outgrowth are thought to be secondary to the effects of neonatal estrogen. The rat hypothalamus and cortex undergo perinatal neuronal organization under the influence of estrogen (formed in situ by aromatization of neonatal testicularly derived androgens), a process called "defeminization" (McEwen et al., 1977; Gorski et al., 1980). For instance, neonatal castration of male rat pups results in a symmetrical cortical mantle (Diamond, 1984). Further, castration of, or administration of an aromatase inhibitor to, neonatal male rats results in decreased size of the adult SDN (both neuron number and synaptic density) (Diamond, 1984; Hammer and Jacobson, 1984), while perinatal androgen or estrogen exposure to neonatal females increases adult SDN size (Jacobson et al., 1981). Conversely, castration or aromatase inhibition of neonatal males facilitates lordotic behavior and LH surges in response to adult estrogen exposure (McEwen et al., 1979), while androgen exposure of neonatal females suppresses these param- 
eters in adulthood (Clemens et al., 1978; Parsons et al., 1984). On a molecular level, sex dimorphisms in mRNA levels for the neural-specific proteins growth-associated protein $43 \mathrm{kDa}$ (GAP43) and synaptosomal-associated protein $25 \mathrm{kDa}$ (SNAP-25) have been noted in the adult rat cortex, which are also determined by the neonatal sex hormonal milieu (Lustig et al., 1993). Although controversial, the presence of plasma $\alpha$-fetoprotein, which binds estrogens avidly in the perinatal period, presumably prevents ovarian-derived plasma estrogen from crossing the blood-brain barrier in females, thus preventing defeminization (Toran-Allerand, 1984). Therefore, it is the ability of plasma androgen to be aromatized to estrogen in the rat brain in situ that dictates whether defeminization will occur.

Estrogen exerts effects on neuritic outgrowth, spine formation, and synaptogenesis in the neonatal rat brain. The addition of $\mathrm{E}_{2}$ to the medium of fetal mouse hypothalamic explants enhances the growth and arborization of neurites (Toran-Allerand et al., 1980, 1983), while addition of antiestrogen antibodies negates the arborization effect (Toran-Allerand, 1980). In fetal neuron cultures, estrogen induces transcription of mRNA for the axon-specific protein tau, and stabilization of microtubules, leading to axonal outgrowth (Ferreira and Caceres, 1991; Diaz et al., 1992), and dendritic outgrowth and arborization (Lorenzo et al., 1992). Ultrastructural studies of the ventromedial hypothalamus (VMH) indicate that the number of axosomatic and axospinous synapses are similar between the sexes at birth, but by adulthood there is a clear male $>$ female sex dimorphism of both types of synapses. Castration of neonatal males reduces the number of adult synapses in these areas to the female level, while testosterone treatment of neonatal females increases the adult synaptic number to that of intact males (Matsumoto and Arai, 1986; Matsumoto, 1991).

Estrogen also alters neural organization in ER-positive areas of the adult rat brain. Several reports have documented increased numbers of synaptic terminals and contacts in the ventromedial hypothalamus (Matsumoto and Arai, 1979; Carrer and Aoki, 1982; Clough and Rodriguez-Sierra, 1983; Pozzo Miller and Aoki, 1991) and midbrain central gray (MCG) (Chung et al., 1988) in adult ovariectomized (OVX) rats given EB. Estrogen administration to OVX or peripubertal rats increases the number and density of dendritic spines in the VMH and hippocampus (HPC) (Frankfurt et al., 1990; Gould et al., 1990; Segarra and McEwen, 1991). Similarly, the number of dendritic spines in the VMH and HPC varies with the estrous cycle (Frankfurt et al., 1990; Woolley and McEwen, 1992), suggesting that the neural circuitry of the VMH is inherently plastic, and is constantly remodeled by the fluctuations of peripheral plasma $\mathrm{E}_{2}$ (Pérez et al., 1993).

Although these in vivo studies document the effects of estrogen on neural structure and plasticity, the data are only indirectly correlated to hormonal changes in physiology, cognition, and behavior. These approaches do not answer molecular or mechanistic questions of how neurons are affected by estrogen. To provide a tool for such investigations, we have created an in vitro system for studying the effects of estrogen on neuronal development. The PC12 cell line served as the basis for such a model. These cells, derived from a rat pheochromocytoma (Greene and Tischler, 1976), have been used to study neuritogenesis and neural gene expression. In the presence of NGF, these otherwise chromaffin cells become postmitotic, and initiate neurite outgrowth (Greene and Shooter, 1980) similar to that seen in vivo and in brain tissue explants in culture. Fur- thermore, these cells are easily transfected by mammalian expression vectors with subsequent $\mathrm{mRNA}$ expression and alteration of their phenotype (Yankner et al., 1990). Wild-type PC12 cells (PC12-WT) express a small amount of ER mRNA in the basal state as determined by reverse transcriptase-PCR (data not shown), but their morphology is altered in response to estrogen only minimally. Federoff et al. (1988) have shown that PC12-WT cells do not alter GAP-43 mRNA transcription in response to estrogen, again suggesting that estrogen responsivity in PC 12 cells is routinely minimal. Thus, these cells are a suitable parent line for studying the effects of estrogen on neurons in vitro. By stably transfecting PC12-WT cells with an expression vector coding for the human ER (hER), we hoped to confer estrogen responsivity and morphologic modifications in accordance with the effects noted above. The construction, molecular characterization, and morphologic analysis of this model are now described.

\section{Materials and Methods}

All reagents were purchased from Sigma (St. Louis, MO), all cell culture products were purchased from GIBCO/Bethesda Research Labs (Grand Island, NY), and all electron microscopy reagents were purchased from EM Science (Gibbstown, NJ) unless otherwise specified.

Expression vectors. For hER transfection, these studies utilized the expression vector $\mathrm{pCMV}$-ER $\alpha$-neo, which was described previously and shown to confer estrogen responsivity on ER-negative MDA-231 breast cancer cells by coding for the full-length 1.8 human estrogen receptor (hER) (Jiang and Jordan, 1992). This 7.35 kilobase (kb) vector consists of a strong constitutive cytomegalovirus immediate-early gene promoter and enhancer, which is known to express in PC12 cells (Donis et al., 1993), spliced to a $4.0 \mathrm{~kb}$ polycistronic DNA coding for both the hER and the enzyme neomycin aminoglycoside phosphotransferase (neo) for selection. As a negative control vector, these studies utilized the pCMVneo vector containing the same CMV promoter and neomycin aminoglycoside phosphotransferase, but without the hER coding region (Jiang and Jordan, 1992). These vectors were a gift from Dr. V. Craig Jordan. Vectors were prepared for transfection by cesium chloride ultracentrifugation.

Cells and stable transfection. PC12-WT cells normally require a substratum of collagen, laminin, or polylysine to adhere and extend neurites, but a clone (provided by Dr. Howard Federoff) has been expanded that will grow on tissue culture plastic without treatment. These PC12-WT cells were grown as previously described (Federoff et al., 1988) in Dulbecco's Minimal Essential Medium (DMEM) with $10 \%$ fetal bovine serum (FBS) and 5\% horse serum (JRH Bioscience, Lenexa, KS). Cells were grown to $50 \%$ confluence and stably transfected by the calcium phosphate method (Chen and Okayama, 1987), using $25 \mu \mathrm{g}$ of each vector for transfection. Transfectants were grown for $2 \mathrm{~d}$, and then selected by addition of G418, a neomycin analog (Bethesda Research Labs), $400 \mathrm{mg} / \mathrm{ml}$, to the media for 3 weeks. Resultant transfected clones were isolated using cloning cylinders (Bellco, Vineland, NJ), and expanded in phenol red (PR)-free DMEM with charcoal-stripped FBS and horse serum (to remove all estrogens), under constant G418 pressure to select for strong expressors of the transfected neomycin resistance gene. Approximately 12 clones from each transfection were expanded and analyzed for estrogen responsivity and ${ }^{3} \mathrm{H}-\mathrm{E}_{2}$ binding. Clones selected for further study were labeled NEO9 (an ER-negative line), and SER8 (an ER-positive line).

$E R$ mRNA expression. For Northern analysis of ER mRNA expression, all three cell lines (PC12-WT, NEO9, SER8) were grown in phenol red (PR)-free DMEM with $10 \%$ charcoal-stripped FBS and $5 \%$ charcoalstripped horse serum (NEO9 and SER8 also with $\mathrm{G} 418,400 \mathrm{mg} / \mathrm{ml}$ ) for $6 \mathrm{~d}$. In addition, MCF-7 breast cancer cells (as an ER-positive control) were grown in Minimal Essential Media with 5\% calf serum. PolyA $^{+}$RNA was prepared using the method of Badley et al. (1988). Cells were washed in cold PBS-aurin-tricarboxylic acid (Boehringer, Indianapolis, IN) and harvested by cell scraping in lysis buffer, and polyA ${ }^{+}$RNA was isolated by incubation with oligo-dT-cellulose (Boehringer) and centrifugation. RNAs from each line were electrophoresed on a $1 \%$ agarose-formaldehyde gel at $25 \mathrm{~V}$ overnight, and transferred to a Hybond-N (Amersham, Arlington Heights, IL) membrane by vac- 


\section{PC12-WT}

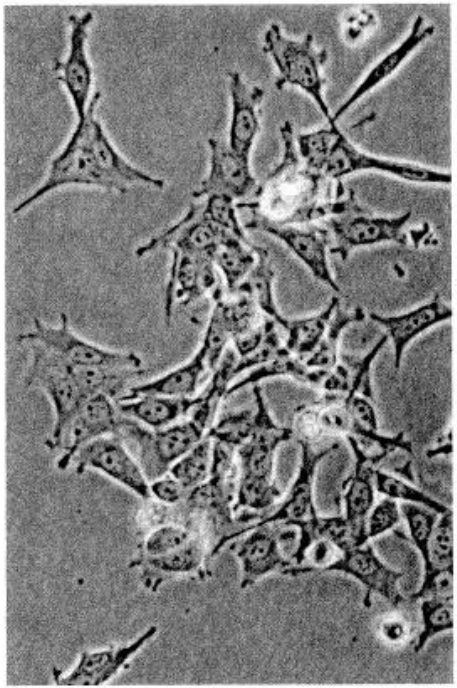

\section{NEO9 \\ ( $T_{x}$ pCMV-neo)}

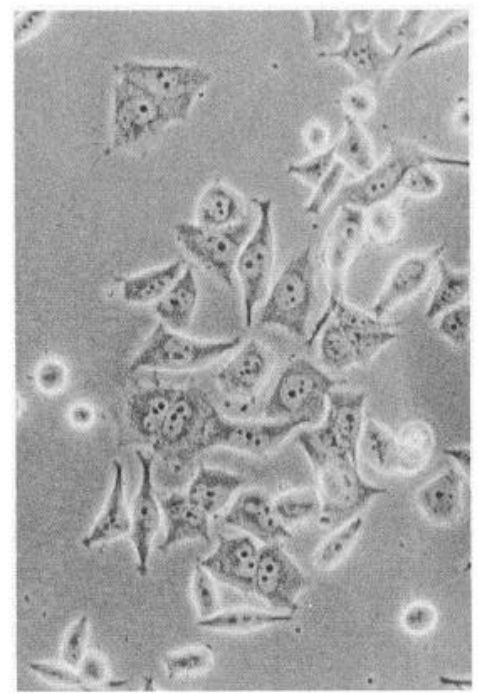

SER8

\section{$\left(T_{x}\right.$ PCMV-ER $\left.\alpha-n e o\right)$}

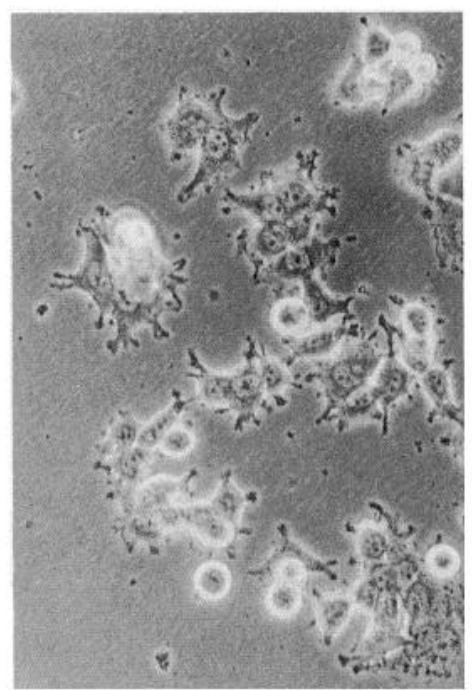

Figure 1. Morphology by inverted phase-contrast LM (400×) of PC12-WT, NEO9, and SER8 cells, when grown in DMEM with $10 \%$ FBS, $5 \%$ horse serum, without exposure to NGF. The SER8 cells demonstrate increased lamellopodia on their surfaces in the basal state.

uum transfer for $3 \mathrm{hr}$. The membrane was UV cross-linked (Stratagene, La Jolla, CA) at $1200 \mathrm{~J}$, and hybridized with the ${ }^{32} \mathrm{P}-\mathrm{hER}$ cDNA (fulllength) in hybridization buffer $\left(5 \times \mathrm{SSC}, 24 \mathrm{mM} \mathrm{Na}_{3} \mathrm{PO}_{4}, 5 \times\right.$ Denhardt's solution, $50 \mu \mathrm{g} / \mathrm{ml}$ denatured salmon sperm DNA, $50 \%$ formamide, $10 \%$ dextran sulfate) overnight. The blot was washed with $2 \times$ SSC, $0.2 \%$ SDS three times at $25^{\circ} \mathrm{C}$, then $0.1 \times \mathrm{SSC}, 0.2 \% \mathrm{SDS}$ at $65^{\circ} \mathrm{C}$ for $10 \mathrm{~min}$, and exposed to autoradiographic film.

Cytosolic ${ }^{3} \mathrm{H}-\mathrm{E}_{2}$ binding assay. Assay for cytosolic ER by ligandbinding assay was performed as described previously (Lustig et al., 1989). All three lines (plus MCF-7 as an ER-positive control) were grown in PR-free DMEM with charcoal-stripped serum $(+\mathrm{G} 418$ for NEO9 and SER8) for $6 \mathrm{~d}$. Cells were trypsinized and harvested, resuspended in $4 \mathrm{ml}$ of buffer containing $0.32 \mathrm{M}$ sucrose, $10 \mathrm{mM} \mathrm{KPO}_{4}, 10 \mathrm{~mm}$ sodium molybdate, and $10 \mathrm{~mm}$ monothioglycerol, homogenized using a Teflon homogenizer (Wheaton), and centrifuged at $105,000 \times g$ for $30 \mathrm{~min}$. Aliquots of resultant cytosol $(100 \mu \mathrm{l})$ were incubated overnight at $4{ }^{\circ} \mathrm{C}$ with $0.1-5 \mathrm{nM}^{3} \mathrm{H}-\mathrm{E}_{2}$ (Amersham) (dissolved in $10 \mathrm{~mm}$ Tris- $\mathrm{HCl}$, $1.5 \mathrm{~mm} \mathrm{Na}_{2}$ EDTA, $10 \%$ glycerol, $1 \mathrm{~mm}$ dithiothreitol, $0.5 \mathrm{~mm}$ bacitracin) in the presence or absence of 200 -fold excess diethylstilbestrol. Incubates were eluted on short LH-20 columns with TEGDB buffer, and the eluate counted in a $\beta$-scintillation counter and standardized for cytosolic protein concentration using the Bradford method (Bradford, 1976).

Quantitative light microscopy. For each experiment, 100 cells per dish were randomly counted by one investigator (R.H.L.) according to a protocol devised to minimize counting bias. Cells were counted at $430 \times$ magnification. Cells which remained round, did not flatten on plastic, and did not express any lamellopodia or neurites were not counted. Cells whose somata abutted other somata were considered crowded, and therefore extended neurites suboptimally, also were not included in the analysis. All other cells were included in the analysis. A potential maximum of six cells per high-power field were counted, and then the field was shifted in a discernable pattern, to prevent recounting the same cell. Cells were assessed for the following parameters: (1) frequency of neuritic outgrowth (number of cells with neurites per 100 cells counted); (2) frequency of short neurites (number of cells with neurites whose lengths were less than two cell body widths/100 cells counted) and density (number per cell) of short neurites; (3) frequency of long neurites (number of cells with neurites whose lengths were greater than two cell body widths/100 cells counted) and density (number per cell) of long neurites; (4) frequency of neuritic spines (varicosities along the length of neurites, perpendicular to the neurite, and very short in length; num- ber of cells with neuritic spines per cells with neurites) and density of spines (number of spines per cell with spines); and (5) frequency of interneuritic interaction [cells whose neurites appear by light microscopy (LM) to be communicating, where a single neurite appears to travel uninterrupted between two separate cell bodies; number of interneuritic interactions per 100 cells counted].

Statistical evaluations were performed by (1) $\chi^{2}$ analysis of the effect of estrogen on the frequency of each parameter at each NGF concentration, with subsequent Fisher's Exact Test; and also by (2) analysis of variance of the effect of estrogen on the density of each parameter, with subsequent post-hoc Bonferroni analysis.

Quantitative electron microscopy. Cultures were fixed in $4 \%$ glutaraldehyde-PBS, postfixed in $1 \% \mathrm{OsO}_{4}$, dehydrated in graded ethanols, and embedded in Epon. Sections were prepared on a Reichert-Jung Ultracut S. Sections were stained with uranyl acetate and lead citrate, and visualized using a JEOL CX-100 electron microscope at $10,000 \times$ magnification. Quantification of ultrastructural characteristics were performed in a blinded fashion on serial electron microscope (EM) negatives.

Dye coupling. Cells growing on polylysine-coated glass coverslips were visualized by differential-interference contrast (DIC) optics (Zeiss Axiovert $35 \mathrm{M}$ ). Cells whose processes abutted on another cell were microinjected with $5 \%$ Lucifer yellow in $50 \mathrm{~mm}$ potassium glutamate buffer, using an Eppendorf 5170 micromanipulation and 5242 microinjection apparatus. Injection volume did not exceed $10 \%$ of the cell's basal volume. The transfer of dye from the injected cell into the secondary abutting cell was determined by epifluorescence.

\section{Results}

Selection of transfected clones and alterations in basal morphology

Figure 1 shows the morphology of PC12-WT, NEO9, and SER8 cells when grown in standard phenol red (PR)-containing medium. PC12-WT cells are pleomorphic, reflecting their inherent heterogeneity, with lamellopodia and early and immature neuritic formation, while NEO9 cells appear more homogeneous, with fewer membrane specializations. In contrast, SER8 cells have a different phenotype, with marked lamellopodial formation along the cell membrane, even in the basal state. 


\section{hER}

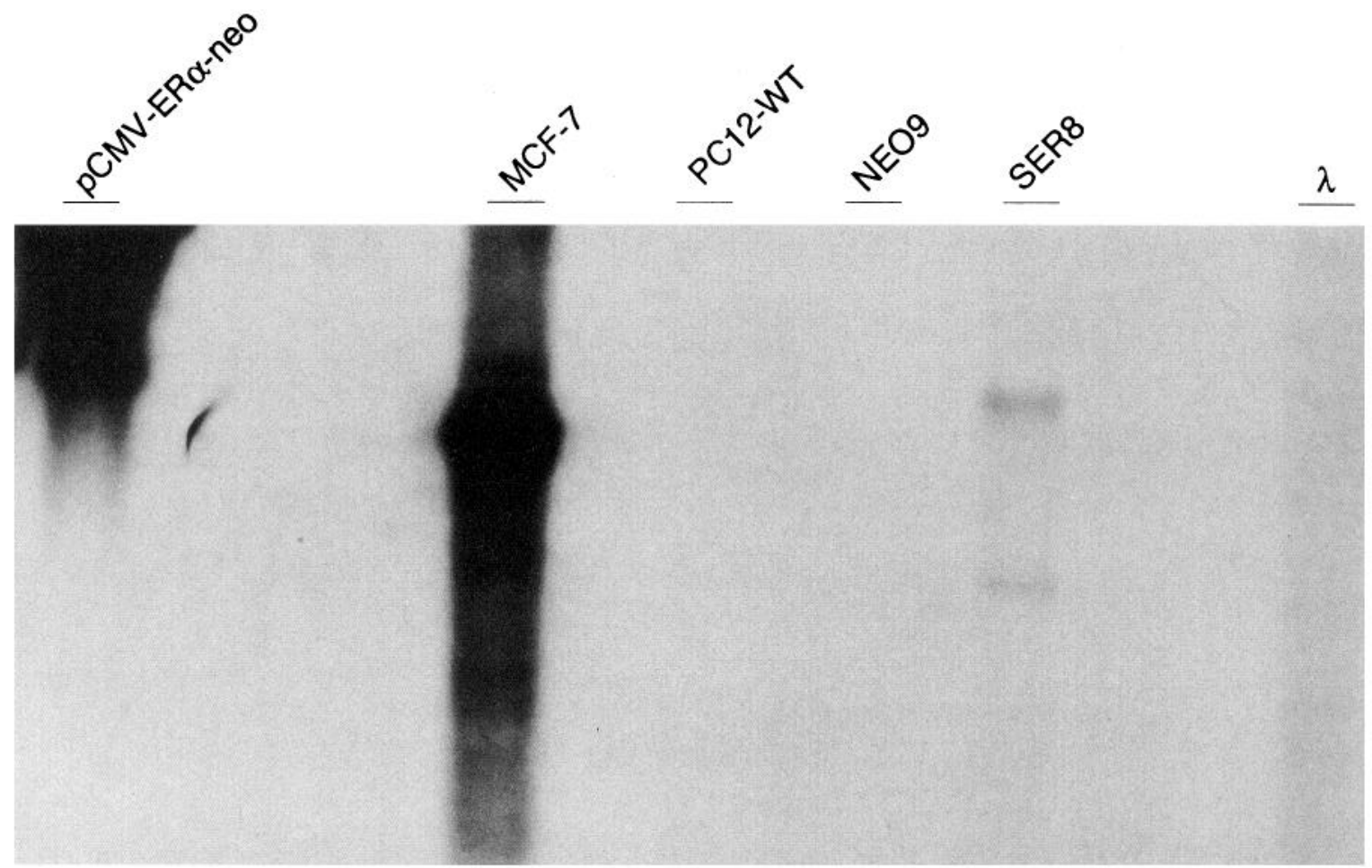

Figure 2. Northern blot of polyA + RNA extracted from MCF-7 breast cancer cells (ER-positive control), and PC12-WT, NEO9, and SER8 cells. Blot was probed with a $1.8 \mathrm{~kb}$ full-length ${ }^{32} \mathrm{P}$-labeled cDNA coding for the hER. MCF-7 cells demonstrate an intense ER mRNA band at $6.2 \mathrm{~kb}$. PC12-WT and NEO9 cells do not demonstrate any bands that hybridize with the hER cDNA probe, but SER8 cells demonstrate two light bands: one at $7.4 \mathrm{~kb}$, which corresponds to the size of the transfected pCMV-ER $\alpha$-neo vector, and a second band at $3.2 \mathrm{~kb}$.

\section{Analysis of ER mRNA expression}

Northern blots were prepared from polyA+ RNA from the different cell lines, and hybridized with ${ }^{32} \mathrm{P}$-labeled cDNA for hER. Results are shown in Figure 2. ER-positive MCF-7 breast cancer cells demonstrate an intense band at $6.2 \mathrm{~kb}$, previously shown to correspond to the hER (Jiang and Jordan, 1992), while PC12WT and NEO9 cells do not demonstrate a band. SER8 cells do not have as much ER mRNA as do MCF-7 cells, but there are two bands at 7.4 and $3.2 \mathrm{~kb}$, suggesting that SER 8 cells express hER mRNA.

\section{Cytosolic ER assay by ${ }^{3} \mathrm{H}-\mathrm{E}_{2}$ binding}

To document functional ER protein, cytosol was prepared from each cell line and incubated with ${ }^{3} \mathrm{H}-\mathrm{E}_{2}$ to determine specific binding. Resultant femtomoles bound is expressed as a Scatchard plot in Figure 3. MCF-7 cells (positive control) demonstrated ${ }^{3} \mathrm{H}-\mathrm{E}_{2}$ specific binding with a $K_{d}$ of $2.2 \mathrm{nM}$, and a $B_{\max }$ of $533 \mathrm{fmol} / \mathrm{mg}$ protein. PC12-WT and NEO9 cells demonstrated less and no specific binding, respectively, and a Scatchard plot could not be drawn. However, SER8 cells demonstrated specific binding with a $K_{d}$ of $6.6 \mathrm{nM}$, and a $B_{\max }$ of $152 \mathrm{fmol} / \mathrm{mg}$ protein. Thus, the SER8 cells expressed an ER species with binding characteristics similar to MCF-7 cells, but with a diminished total ER concentration.

\section{Light microscopic alterations of PC12 cell phenotype after $N G F$ and estrogen incubation}

To determine if estrogen has any effect on the morphologic phenotype of PC1 2 cells, the three lines were plated at a density of $35,000-40,000$ cells per $35 \mathrm{~mm}$ dish. Cells were allowed to attach overnight, and then incubated with graded doses of NGF $(0,1$, and $100 \mathrm{ng} / \mathrm{ml})$, along with graded doses of $E_{2}\left(0,10^{-10}\right.$, $10^{-9} \mathrm{M}$ ) in $0.1 \%$ ethanol for $2 \mathrm{~d}$. Cells were fixed in $4 \%$ glutaraldehyde-PBS, examined under high-power light microscopy (LM), and quantified for total neurites, short neurites, long neurites, neuritic spines, and interneuritic interactions (see Materials and Methods). Representative cells are shown in Figure $4 a-c$. In Figure $4 a$, addition of NGF to PC12-WT cells caused them to extend neurites, and the coadministration of $E_{2}$ led to some lamellopodia formation, with occasional neuritic spines and interneuritic interaction. In Figure $4 b$, NEO9 cells demonstrated equivalent neuritic outgrowth with NGF, but coadministration of $E_{2}$ had no effect on spine formation or interneuritic interaction. In Figure $4 c$, in the absence of NGF, SER 8 cells showed baseline lamellopodia formation, and the addition of $\mathrm{E}_{2}$ led to the formation of some neurites. Administration of NGF led to neuritic outgrowth with some spine formation and interneuritic interaction in the absence of $E_{2}$, and addition of $E_{2}$ augmented these parameters, suggesting that $E_{2}$ was able to synergize with NGF. These findings are quantitated in Figure 5. $\mathrm{E}_{2}$ demonstrated an additive effect with low-dose NGF on the frequency of both short and long neurite outgrowth in SER8 cells $(P<0.05)$, although the effect was not as noticeable at the higher dose of NGF, but there was no effect of estrogen in either PC12-WT or NEO9 cells. Furthermore, $\mathrm{E}_{2}$ induced an increased frequency of neuritic spine formation and interneuritic interaction in SER 8 cells, which again was most notable at low levels of NGF $(P<0.05)$, but again minimal and no effects were noted on PC12-WT and NEO9 cells, suggesting that these frequency 
parameters are induced by estrogen. 'The density of each of the parameters analyzed did not demonstrate any estrogen effect.

\section{Blockade of estrogen effect on SER8 cell morphology by coadministration of an antiestrogen}

To determine the nature of the $\mathrm{E}_{2}$ effect on SER8 cells, a corollary LM experiment was conducted in which the three cell lines were harvested, plated, and exposed to $100 \mathrm{ng} / \mathrm{ml} \mathrm{NGF}$ with the following steroid treatments for $2 \mathrm{~d}$ : (1) $0 \mathrm{M} \mathrm{E}_{2}$; (2) $10^{-9} \mathrm{M} \mathrm{E}_{2}$; (3) $10^{-9} \mathrm{M} \mathrm{E}_{2}+2 \times 10^{-8} \mathrm{M}$ ICI 164,384 (ICI, Cheshire, UK), a pure antiestrogen that binds to the ER (Gottardis et al., 1989), 20 -fold excess over $\mathrm{E}_{2}$ dose; and (4) $10^{-9} \mathrm{M} \mathrm{E}_{2}+2 \times 10^{-7} \mathrm{M}$ ICI, a 200-fold excess. Cells were again fixed, and underwent quantitative light microscopy, as above. The quantitative results of this study are shown as histograms in Figure 6. Since this dose of NGF was maximal, these was no augmentation of neuritic outgrowth with $\mathrm{E}_{2}$ in any cell line. ICI coadministration had little effect on PC12-WT or NEO9 cells. However, the aforementioned $E_{2}$-induced increases in spine formation and interneuritic interaction in SER8 cells were negated in a dose-dependent fashion by the coadministration of ICI.

\section{Estrogenic induction of gap junctions}

Electron microscopy ( $E M)$. To characterize the estrogen-induced interneuritic connections, the ultrastructure of cells from all three lines exposed to $\mathrm{NGF}$ and $\mathrm{E}_{2}$ was examined. In particular, interneuritic abutments were visualized. In general, there were two types of abutments that differed in their ultrastructural appearance. Both types of abutments were present in all cell lines, and in the presence and absence of $E_{2}$. The first type of abutment was nonspecialized in appearance, with the cell membranes of the two neurites simply coming into apposition. The other type of abutment was highly specialized in appearance, with many thickened and darkly stained cell membranes on either side of the abutment. The appearances of the membranes on both sides of the abutment were similar, and showed no detectable asymmetries. Very high magnification and image tilting at the electron microscope indicated a layered appearance to the membrane. These observations led to the inference that these specialized abutments were gap junctions. Examples of these membrane specializations are depicted in Figure 7. It is also noted that there were no true synapses observed in any of the cell lines or estrogen conditions.

Consistent with the LM work, quantification of the number of abutments and the proportion that resembled gap junctions varied between cell lines and estrogen exposure (Table 1). PC12WT and NEO9 cells only occasionally exhibited putative gap junctions, with no increase in frequency or length with $E_{2}$ administration. SER8 cells exhibited more frequent putative gap
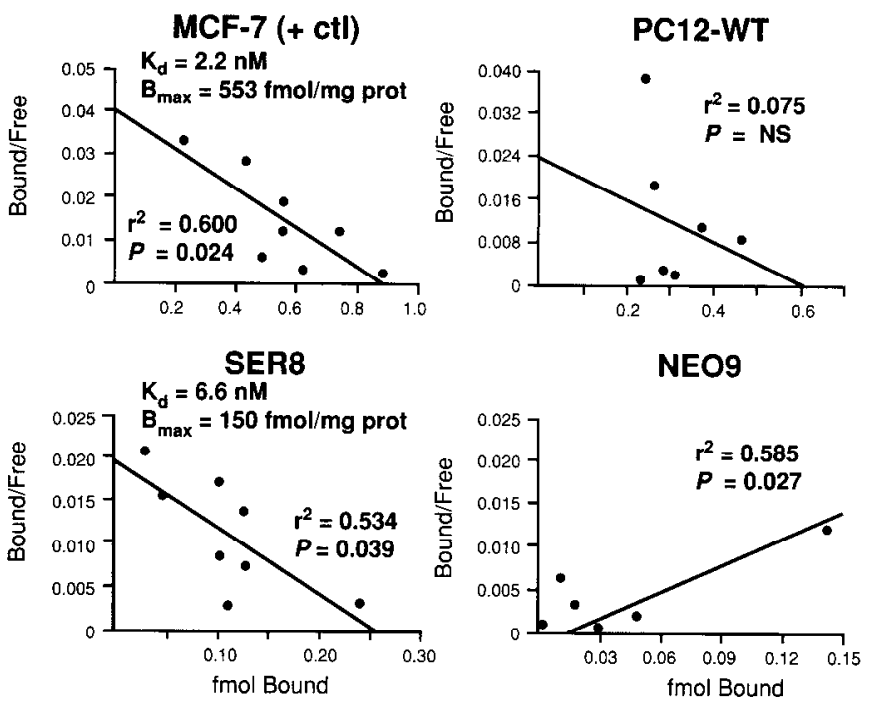

Figure 3. Scatchard plots calculated from ${ }^{3} \mathrm{H}-\mathrm{E}_{2}$ specific binding for MCF-7 (ER-positive control) cells, along with PC12-WT, SER 8, and NEO9 cells. MCF-7 and SER8 cells both demonstrate a linear correlation $(P<0.05)$, suggesting only one binding site, with $K_{d}$ calculations of 2.2-6.6 nM, which approximate that reported for hER in the literature.

junctions at the abutments of cells in the absence of $E_{2}$, and markedly increased both their frequency and length with $\mathrm{E}_{2}(P$ $<0.05$ ).

Dye coupling. To determine whether the specialized abutments observed under EM were indeed functional gap junctions, the transfer of dye between cells was assessed. Cells of each line were plated on polylysine-coated glass coverslips, exposed to $100 \mathrm{ng} / \mathrm{ml} \mathrm{NGF}$ with or without $10^{-9} \mathrm{M} \mathrm{E}_{2}$ for $2 \mathrm{~d}$, and visualized by DIC microscopy. Abutments of neurites were determined visually. The cell body of one of the two neurites was microinjected with $5 \%$ Lucifer yellow. The neurites were defined as dye coupled if the second abutting but noninjected cell glowed under the epifluorescence beam 1 min after the first cell was injected. Examples of dye coupling are shown in Figure 8. PC12-WT and NEO9 cells demonstrated only rare dye coupling, either basally or with estrogen treatment. Conversely, SER 8 cells showed relatively frequent dye coupling in the basal state, and a marked increase with $E_{2}$ treatment. Quantitative analysis of dye coupling is shown in Table 1. PC12-WT and NEO9 cells dye coupled with minimal frequency, with essentially no change with estrogen treatment. However, SER 8 cells showed higher basal dyecoupling frequency, which more than doubled after $\mathrm{E}_{2}$ administration $(P<0.05)$. The frequency of SER 8 cell dye coupling was consistent with the EM data shown above.

Table 1. Effects of estrogen on gap junction frequency, gap junction length, and dye coupling

\begin{tabular}{|c|c|c|c|c|c|c|}
\hline \multirow[b]{2}{*}{ Parameter } & \multicolumn{2}{|c|}{ PC12-WT } & \multicolumn{2}{|l|}{ NEO9 } & \multicolumn{2}{|l|}{ SER 8 } \\
\hline & $0 \mathrm{M} \mathrm{E}_{2}$ & $10^{-9} \mathrm{M} \mathrm{E}_{2}$ & $0 \mathrm{ME}_{2}$ & $10^{-9} \mathrm{M} \mathrm{E}_{2}$ & $0 \mathrm{M} \mathbf{E}_{2}$ & $10^{-9} \mathrm{M} \mathrm{E}_{2}$ \\
\hline Frequency of abutments with gap junctions (\%) & 8.2 & 21.0 & 15.7 & 12.7 & 21.0 & $46.9 *$ \\
\hline Length of abutments with gap junctions (\%) & 6.8 & 8.3 & 2.8 & 2.6 & 13.6 & $51.8^{*}$ \\
\hline Frequency of dye coupling & $2 / 20$ & $3 / 20$ & $1 / 20$ & $1 / 20$ & $4 / 20$ & $9 / 20^{*}$ \\
\hline
\end{tabular}

Cells were grown for $2 \mathrm{~d}$ in DMEM with $100 \mathrm{ng} / \mathrm{ml} \mathrm{NGF}$, in the absence or presence of $10^{-9} \mathrm{M} \mathrm{E}_{2}$. Gap junction length and frequency were determined by electron microscopy, and dye coupling was determined by DIC microscopy and fluorescence.

* Fisher's exact test $P<0.05$. 
PC12-WT
(+ ER)

- NGF

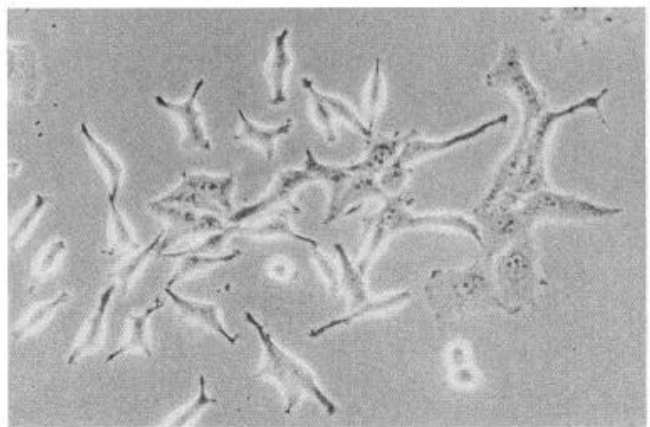

$+\mathrm{NGF}$

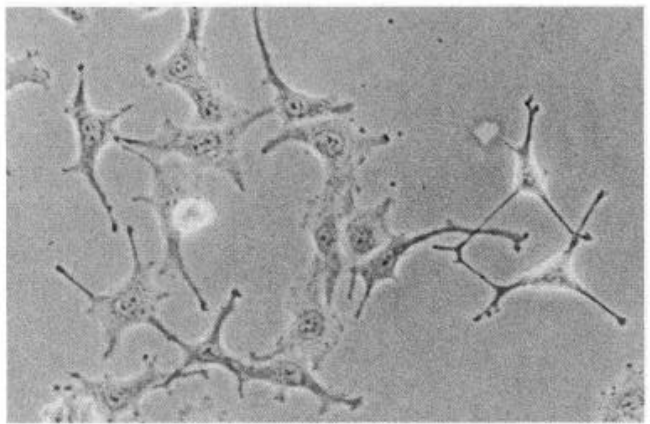

\section{NEO9 \\ (-ER)}

- NGF

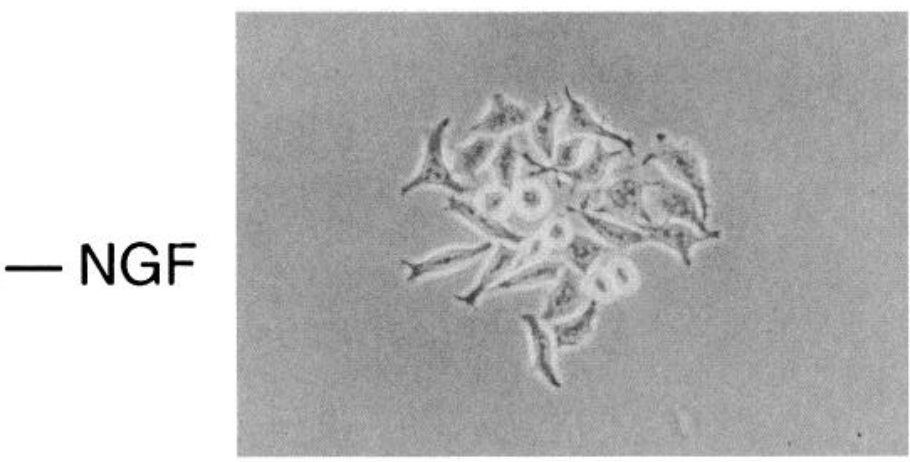

$-E_{2}$

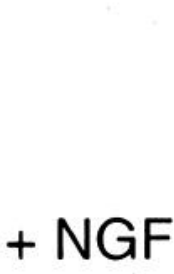

$+E_{2}$
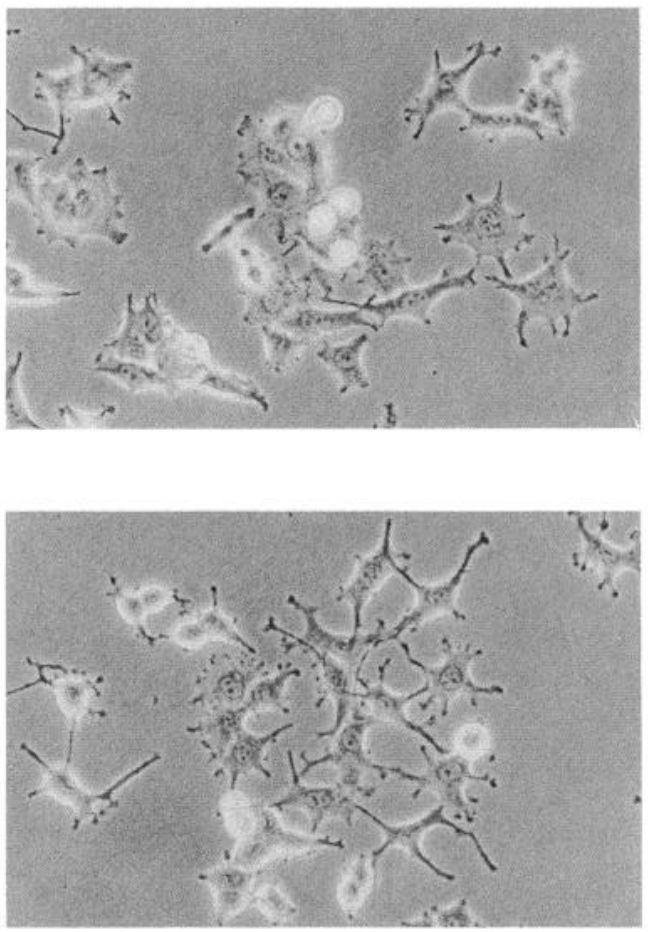

$+E_{2}$
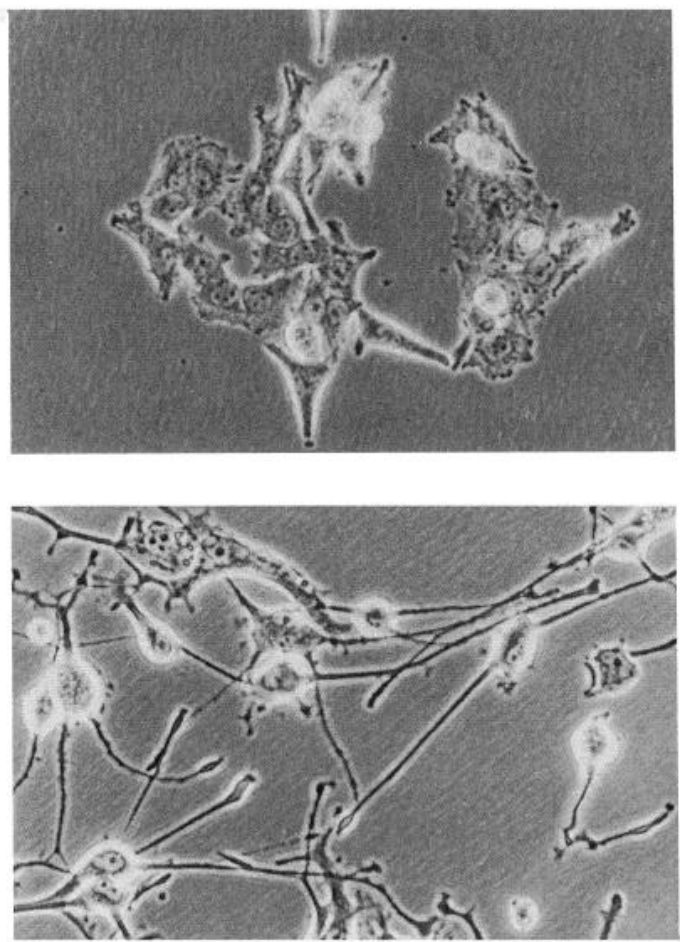

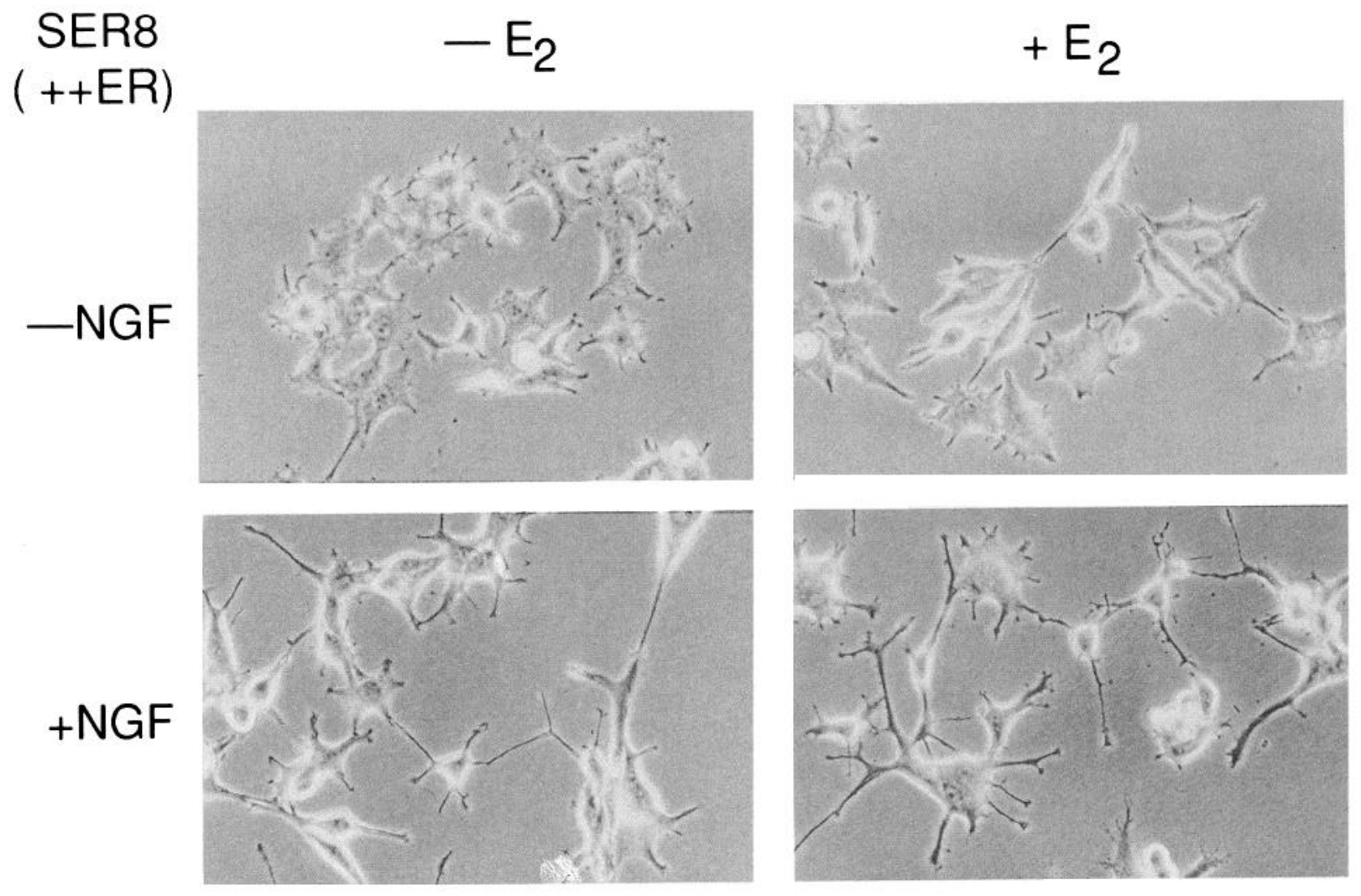

Figure 4. Continued.

\section{Discussion}

The results of these experiments show that estrogen has very specific effects on PC12 cells. In hER-expressing SER8 cells, estrogen has the ability to increase neurite outgrowth in the absence of NGF, and to synergize with NGF to augment the frequency of short and long neurite outgrowth. Several investigators (Toran-Allerand, 1980; Toran-Allerand et al., 1983; Diaz et al., 1992; Lorenzo et al., 1992) have clearly demonstrated the ability of estrogen to induce or augment neurite outgrowth in ER-positive neurons. As a corollary to this phenomenon, estrogenic regulation of mRNA levels for the axonal growth protein GAP-43 in VMH has also been noted (Lustig et al., 1991; Shughrue and Dorsa, 1993). The neuritic growth responses of SER 8 cells to estrogen, even in the absence of NGF, are consistent with the hypothesis that estrogen is able to induce neurite outgrowth in ER-positive neural cells in vitro. Of note was the ability of estrogen to increase the frequency, but not the density, of these parameters. This suggests that estrogen increases the propensity for cells to elongate their processes, which alters their potential for interaction but does increase their inherent ability to form these processes. A similar effect of es- trogen on neurite outgrowth was recently reported in an ERtransfected neuroblastoma cell line (Ma et al., 1993), suggesting that various cells of neural crest origin may retain the capacity to respond to estrogen by increasing the propensity for augmenting neurite outgrowth.

In addition, estrogen induces neuritic spine formation and interneuritic interaction in PC12 cells. Thus, the effects of estrogen on SER8 cells appear to be similar to the effects of estrogen on ER-positive neurons and areas of the rat brain in vivo (Gould et al., 1990; Ferreira and Caceres, 1991; Segarra and McEwen, 1991; Diaz et al., 1992; Lorenzo et al., 1992; Woolley and McEwen, 1992). The ability of an antiestrogen to negate the $E_{2}$ effect in a dose-responsive fashion implies that the $E_{2}$ effects on SER8 cells are mediated through standard estrogenER ligand-receptor interactions, rather than through any secondary phenomenon (e.g., direct membrane effects, cell metabolism, etc.).

Jones et al. (1986) showed that estrogen induces ribosomal RNA (rRNA) levels in VMH and amygdala (both ER-positive areas of the adult rat brain) within $6 \mathrm{hr}$. Steward and Falk (1991) have proposed that newly synthesized RNA is transported to the dendritic spine as polyribosomes, where they form clusters

Figure 4. Effects of NGF and estradiol $\left(\mathrm{E}_{2}\right)$ on the morphology by LM $(400 \times)$ of three lines of PC12 cells. In the NGF-deprived state (upper two panels of $a-c$ ), cells only occasionally establish neurites. NGF $100 \mathrm{ng} / \mathrm{ml}$ administration (lower two panels of $a-c$ ) induces neurite outgrowth in all lines. PC12-WT cells $(a)$ and NEO9 cells $(b)$ both exhibit neurite outgrowth in response to NGF, but $\mathrm{E}_{2}$ coadministration has minimal or no morphologic effect with respect to neurites, spines, or interneuritic connections. In SER8 cells (c), even without NGF, $E_{2}$ induces neurite outgrowth, and when given in conjunction with $\mathrm{NGF}, \mathrm{E}_{2}$ is able to augment neurite outgrowth and also increase neuritic spine formation and interneuritic connections. 
TOTAL NEURITES
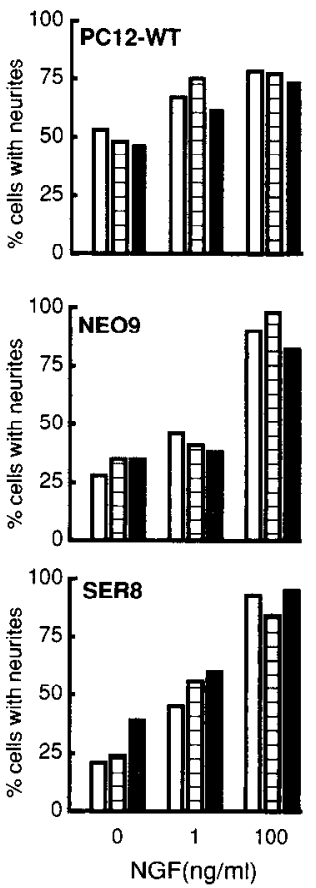

SHORT NEURITES
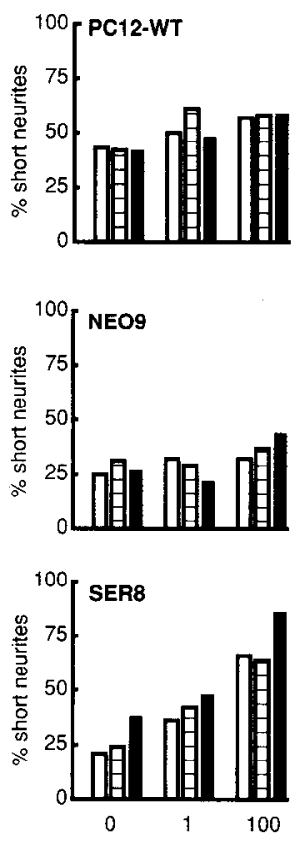
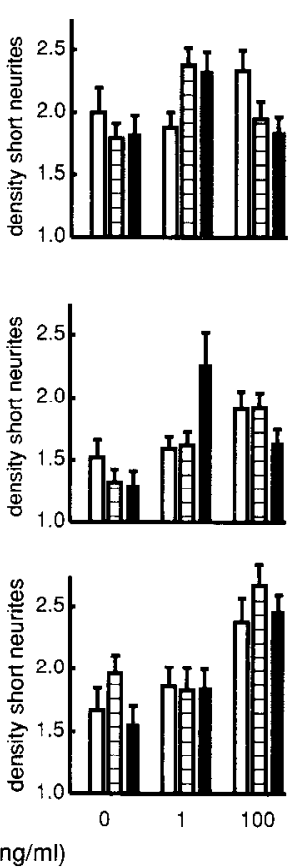

LONG NEURITES
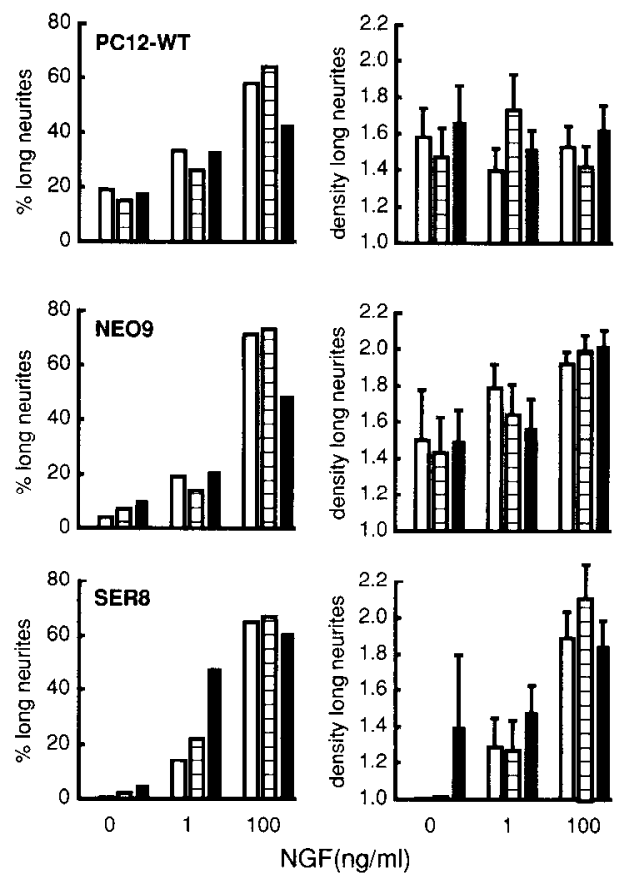

\section{NEURITIC SPINES}
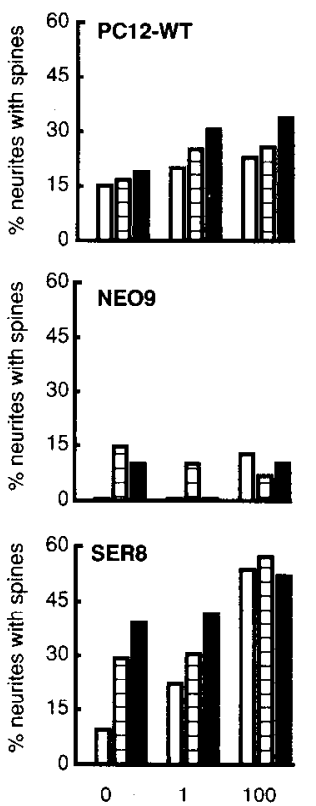
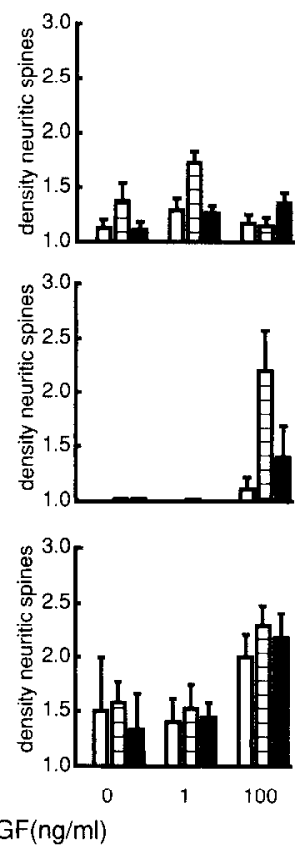

INTERNEURITIC CONNECTIONS

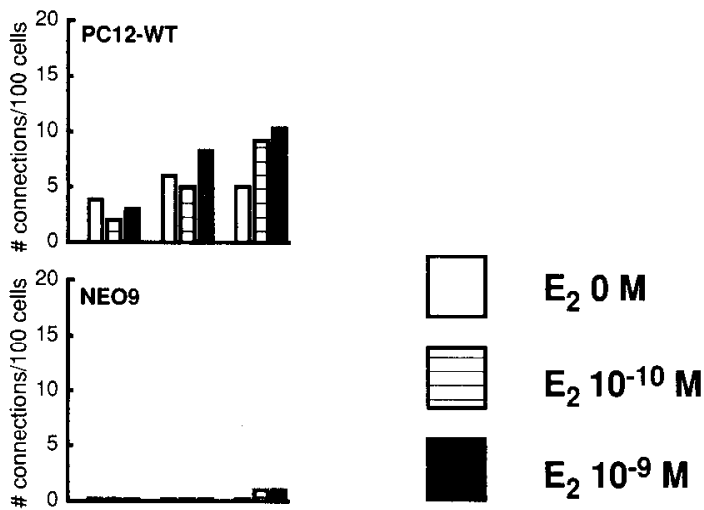

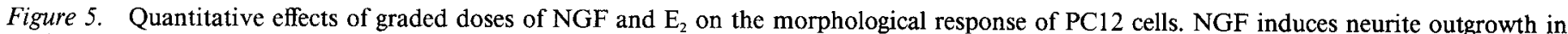

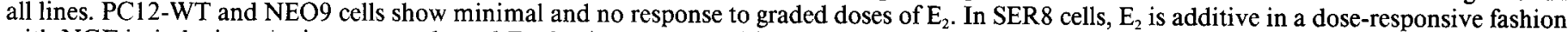
with NGF in inducing neurite outgrowth, and $\mathrm{E}_{2}$ also increases neuritic spine formation and intcrncuritic connections.

and provide the biochemical machinery for local protein synthesis in the spine (Steward, 1983; Steward and Reeves, 1988; Rao and Steward, 1991; Steward and Falk, 1991). Axonal growth cones make contact with the spine, and this complex forms into an axospinous synapse (Steward et al., 1988). Spines and polyribosomes both increase during the period of synaptogenesis in hippocampus (Steward et al., 1988). The relative lack of spines in both the PC12-WT and NEO9 cells thus corresponds with previous reports of a relative lack of ribosomes within the $\mathrm{PC} 12$ neurite (Jacobs and Stevens, 1986). However, the abundance and the estrogenic regulation of neuritic spines in hER-positive SER 8 cells suggest the ability of estrogen to enact a neural mor- 
TOTAL NEURITES
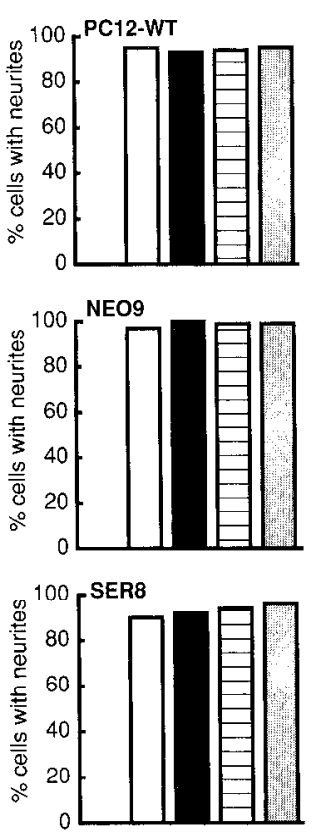

NGF $100 \mathrm{ng} / \mathrm{ml}$

\section{SHORT NEURITES}
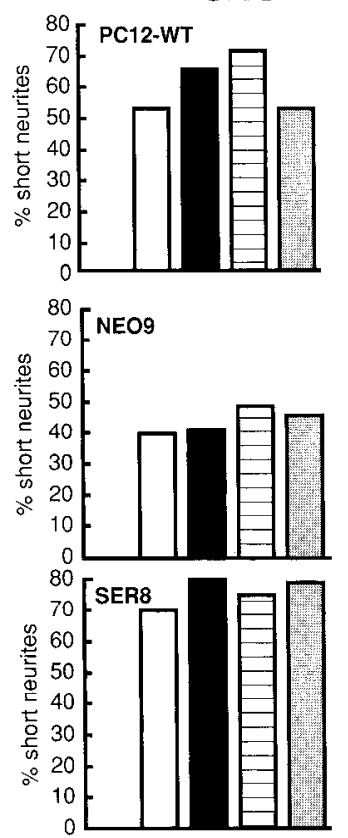

NGF $100 \mathrm{rg} / \mathrm{m} \mathrm{ml}$

$100 \mathrm{rg} / \mathrm{m}$
LONG NEURITES
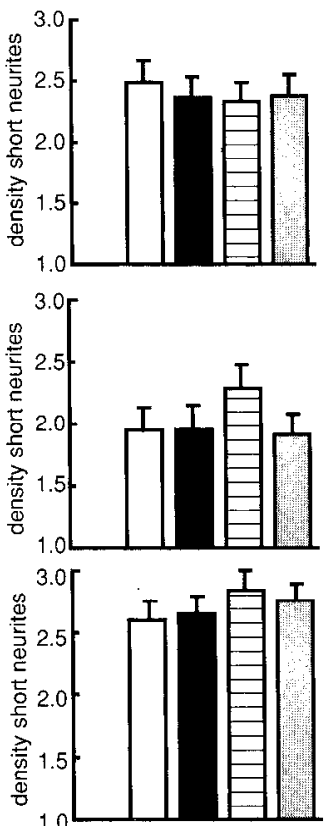

$\mathrm{NGF} 100 \mathrm{ng} / \mathrm{ml}$
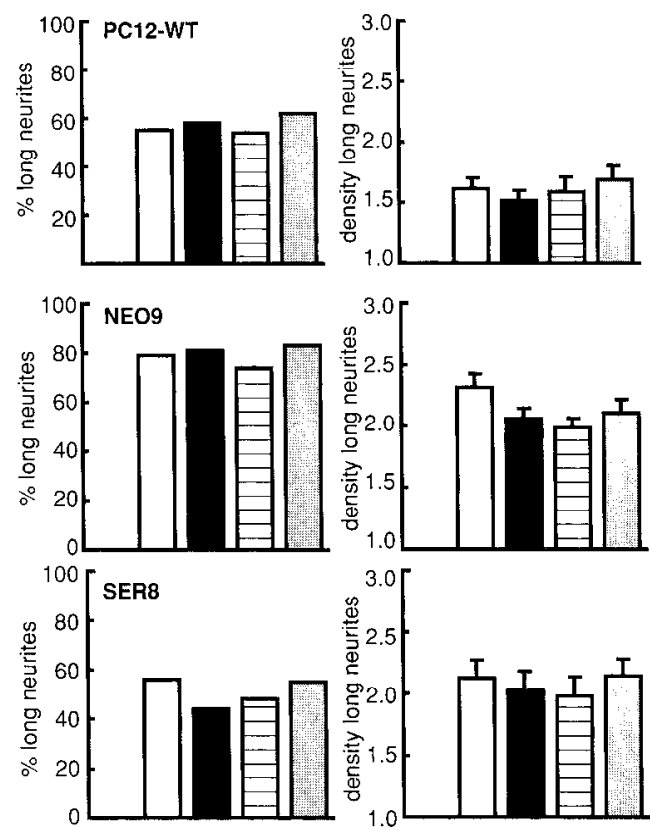

NEURITIC SPINES
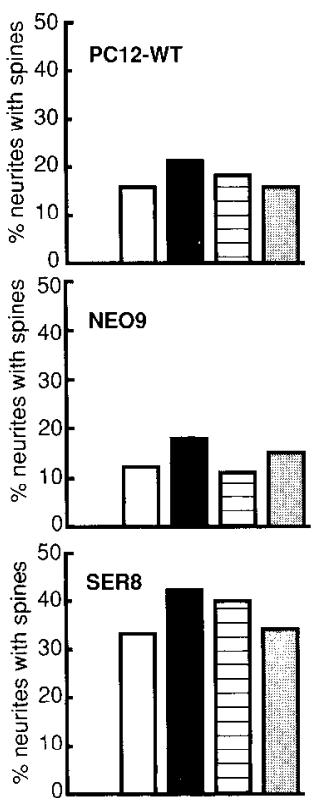

NGF $100 \mathrm{ng} / \mathrm{ml}$

\section{INTERNEURITIC CONNECTIONS}
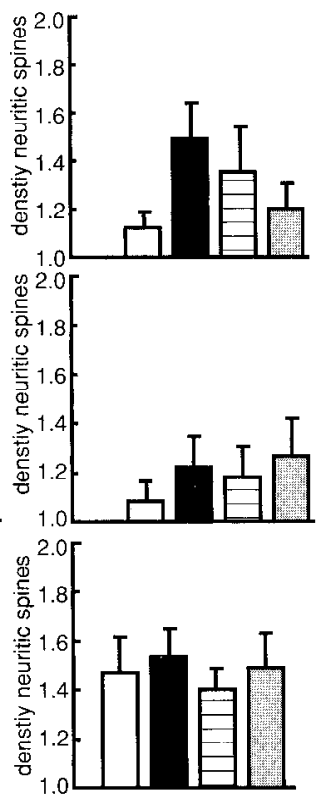
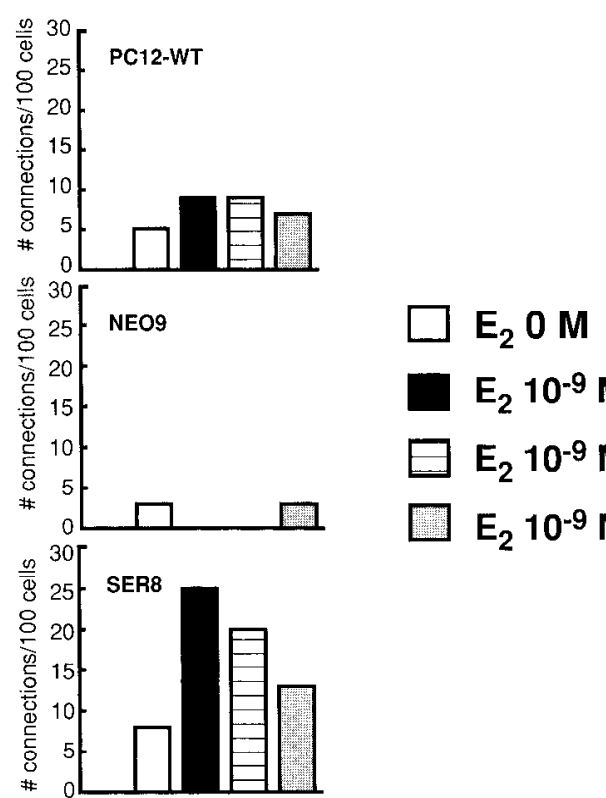

D $E_{2} 10^{-9} \mathrm{M}$

$E_{2} 10^{-9} \mathrm{M}+\mathrm{ICl} 2 \times 10^{-8} \mathrm{M}$

$E_{2} 10^{-9} \mathrm{M}+\mathrm{ICl} 2 \times 10^{-7} \mathrm{M}$

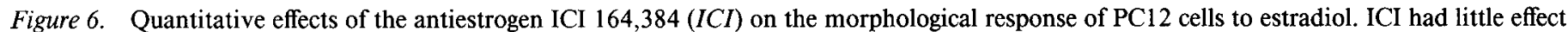

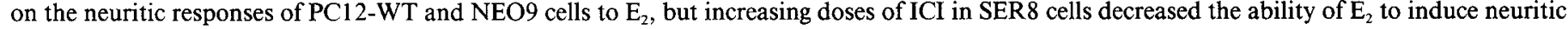
spines and interneuritic interactions.

phologic program necessary to promote intercellular communication, which may be inherent in many types of neural cells. The evaluation of the estrogenic regulation of ribosomes, synaptic vesicles, and synapse-associated proteins in these cell lines will be the subject of future studies.

In addition, $\mathrm{E}_{2}$ alters the communication between SER 8 cells by inducing the formation of gap junctions, allowing for electrolyte, small particle transfer, and electrical coupling between cells. Estrogen has previously been noted to induce gap junctions in the uterus (MacKenzie and Garfield, 1985; Petrocelli and Lye, 1993); this phenomenon is thought to be important in parturition, when electrical coupling of myometrial cells allows for synchronous contraction of the uterus (MacKenzie and Garfield, 1985; Lye et al., 1993). Thus, there is precedence for the estrogenic induction of gap junctions in excitable cells. Documentation of the ability of estrogen to induce neural gap junc- 


\section{$100 \mathrm{ng} / \mathrm{ml} \mathrm{NGF}$}
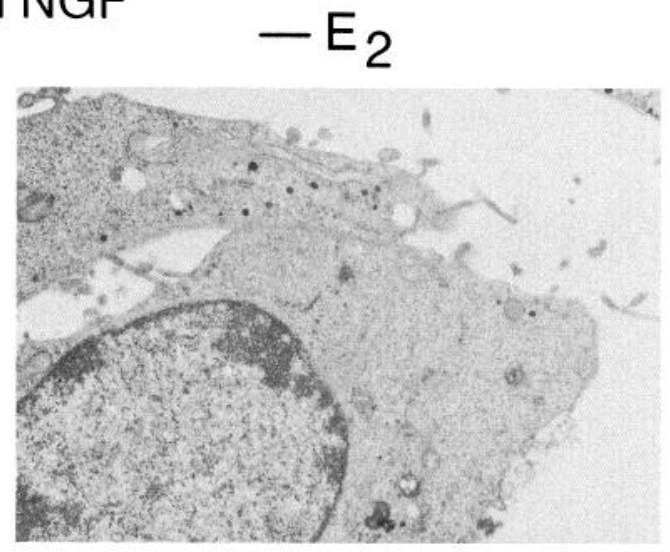

NEO9
$(-E R)$

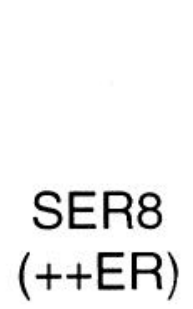

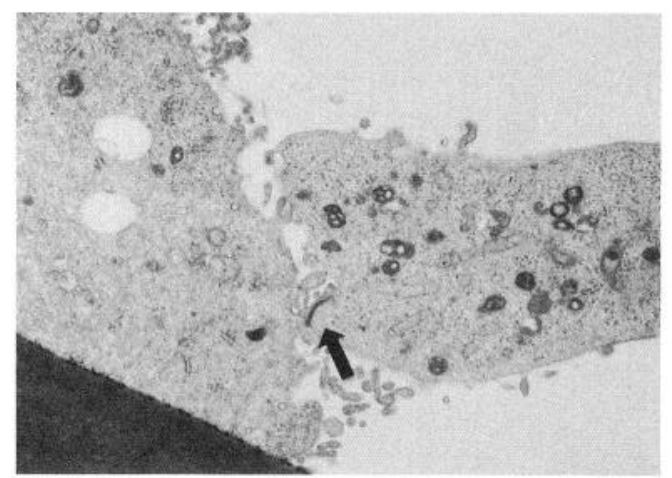
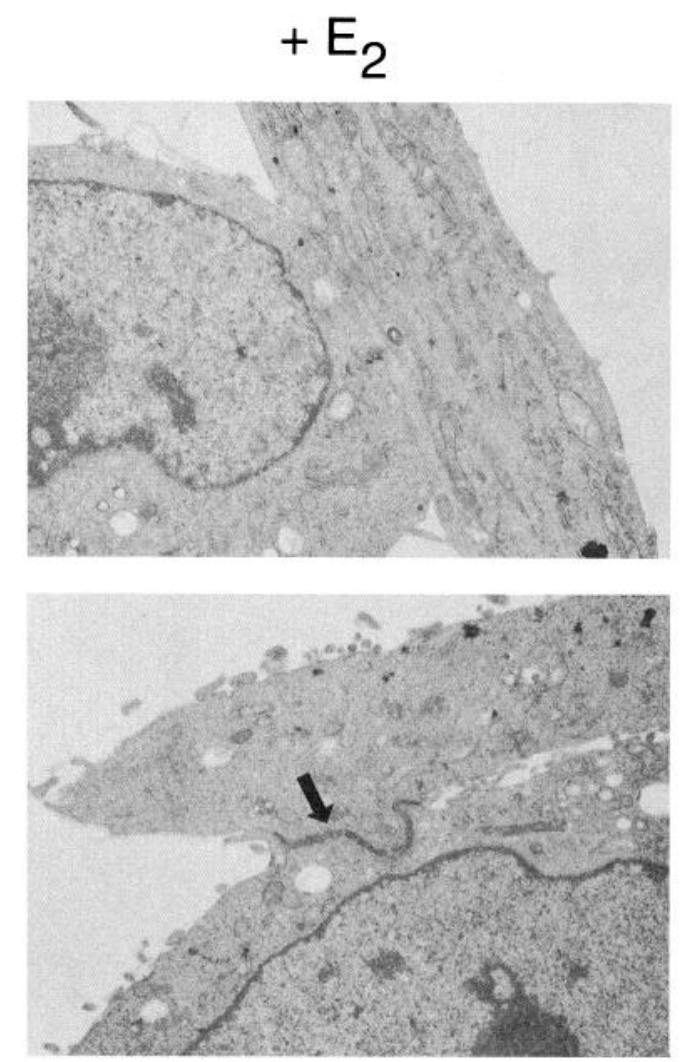

Figure 7. EM evidence for gap junctions in PC12 cells $(10,000 \times)$. NEO9 cells treated with $100 \mathrm{ng} / \mathrm{ml}$ NGF only rarely showed membrane specializations consistent with gap junctions in the absence or presence of $E_{2}$. The predominant form of abutments in these cell lines was that of direct membrane apposition. Conversely, SER8 cells treated with NGF demonstrated these specializations (depicted by arrows) in the absence of $E_{2}$, and increased their number and length markedly in response to $E_{2}$ coadministration.

tions in vivo is less clear. Of note are studies by Hatton et al. $(1990,1992)$ indicating bidirectional changes in dye coupling in response to estrogen versus lactation in the supraoptic oxytocinergic system. Similarly, Theodosis and Poulain (1989) found alterations in neural-glial interactions in the paraventricular nucleus during lactation. These data suggest that estrogen-induced alterations in gap junctions in ER-positive areas may modulate the hypothalamic response to parturition.

The formation of gap junctions has been shown to be important in early intercellular communication between neurons during development, particularly at a time when synaptogenesis is beginning (Naus et al., 1988; Dermietzel et al., 1989; Peinado et al., 1993). The relative frequency of dye coupling between neurons in the rat neocortex in vivo during days P1-P12, with subsequent diminution (Peinado et al., 1993), suggests that gap junctions are a transient and short-lived phenomenon. Their egress at the same time that cortical synaptogenesis is occurring suggests a temporal relation between electrical and chemical transmission, and suggests an ontogenic role for gap junction expression in the sex- and hormone-dependent dimorphisms in neural architecture, synaptogenesis, and reproductive physiology. However, such an association is extremely difficult to test in vivo because of the heterogeneity of the brain and the inability to follow a gap junction serially in vivo. However, this hypothesis may be testable in vitro by monitoring the potential metamorphosis of gap junctions into synapses in SER8, NEO9, and PC12WT cells by EM and dye-coupling methods.

Molecular studies of connexin expression in the neonatal rat brain have implicated estrogen as a potential regulatory signal of gap junction function. Matsumoto et al. (1991) have shown that connexin-32 mRNA can be found by in situ hybridization in areas of the neonatal rat brain that are ER-positive, for example, the hippocampus and anterior hypothalamus. Similarly, Naus et al. $(1988,1990)$ found high levels of connexin-32 mRNA in developing rat neocortex and hypothalamus (both ER-positive areas in the neonate) that decrease after day 19, when ER levels fall (Shughrue et al., 1990; Toran-Allerand et al., 1992), suggesting that gap junctions may be an early form of communication between hormone-responsive neurons in the neonatal rat brain, which may later be modified or cleared when synaptogenesis becomes the predominant form of intercellular communication.

Various connexins may have specific cellular localizations. Matsumoto et al. (1991), using in situ hybridization with a ${ }^{35} \mathrm{~S}$ labeled connexin-32 (liver-derived) cDNA probe, demonstrated silver grains over neurons in the hippocampus, anterior hypothalamus, and other limbic structures. However, Yamamoto et al. (1992), using a site-specific antibody to connexin-43 (heartderived), demonstrated by ICC and EM that while there was a clear differential distribution of this connexin during neural development (including staining in the hypothalamus), there was a clear predilection of the antibody for glial and ependymal cells, with no staining in either oligodendrocytes or neurons. It is not clear if the discrepancy is protein or method specific. Naus and colleagues have demonstrated regional differences in the expression of the two connexins; connexin- 43 mRNA is more 


\section{DYE-COUPUNG $\quad 100 \mathrm{ng} / \mathrm{ml} \mathrm{NGF}+10^{-9} \mathrm{M} \mathrm{E}_{2}$}

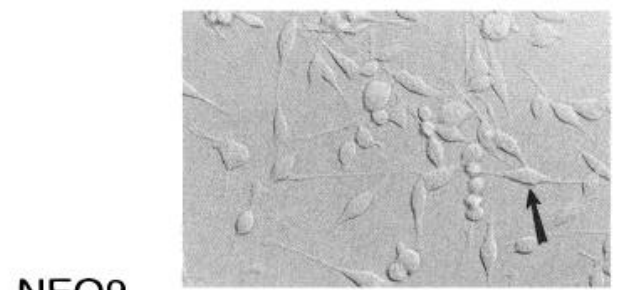

NEO9

(一ER)
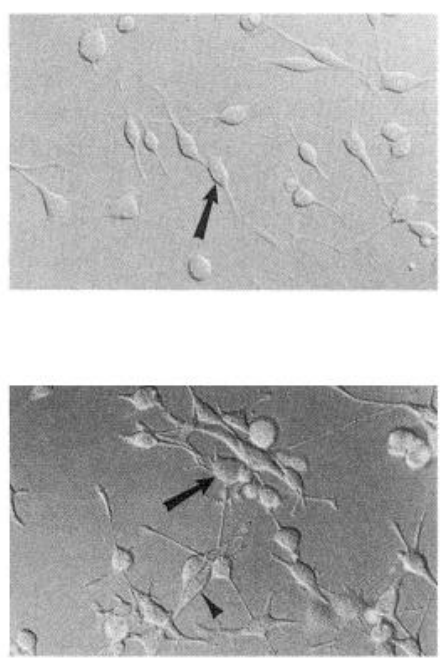

SER8
$(++$ ER $)$

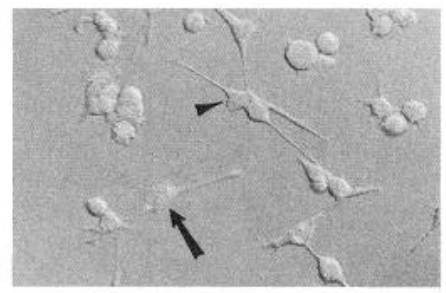

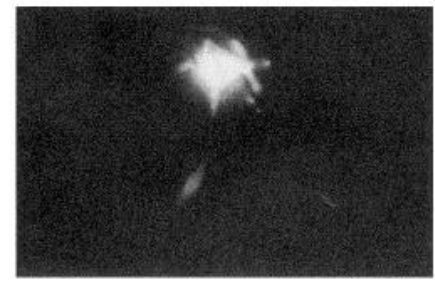
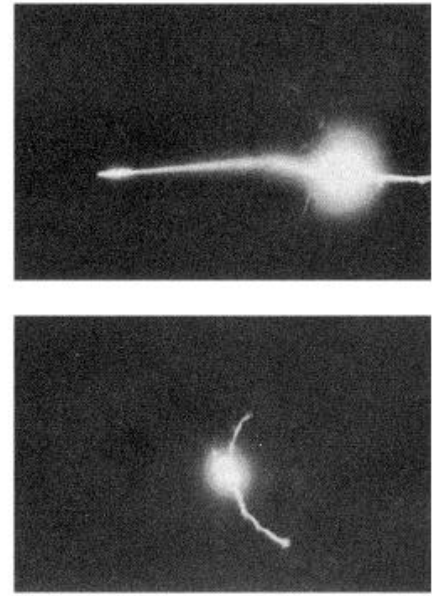

Figure 8. Representative examples of the absence or presence of dye coupling after NGF, $100 \mathrm{ng} / \mathrm{ml}$, and $\mathrm{E}_{2}, 10^{-9} \mathrm{M}$, for $2 \mathrm{~d}$ in NEO9 and SER 8 cells $(400 \times)$. The left panels depict cell morphology with DIC microscopy, and the right panels depict injected and dye-coupled cells glowing under epifluorescence. $A r$ rows depict injected cells, while arrowheads depict dye-coupled cells. NEO9 cells dye-coupled only rarely and $E_{2}$ was ineffective in increasing dye coupling, as demonstrated by the lack of secondary epifluorescence of cells in this figure. SER 8 cells dye coupled frequently in the absence of $E_{2}$, along with increasing dye-coupling frequency with concomitant $\mathrm{E}_{2}$ treatment. ubiquitous, and connexin-32 mRNA is more localized, particularly in the hypothalamus (Naus et al., 1990). Lastly, Dermietzel et al. (1989) localized connexin-26 to non-neuronal tissue in the embryonic brain; however, a recent report by Matesic et al. (1993) documents the expression of connexin-26 in the cell line GT1-7, suggesting neuronal localization. Experiments delineating the type and hormonal regulation of connexin mRNA expression in SER8 cells are currently underway.

In conclusion, these three cell lines form the basis of an in vitro model for estrogen effects on neurons. We anticipate exploiting them to examine the effects of estrogen in a homogeneous neural cell population. Biochemical and gene regulation studies can be performed in culture, as well as developmental studies regarding changes after prolonged NGF and estrogen exposure as well as withdrawal. Ultrastructural and electrophysiologic studies can also be accomplished. Finally, mechanistic studies evaluating the role of specific proteins or mRNAs in sex- and hormone-dependent neural development can be addressed.

\section{References}

Arnold A, Gorski RA (1984) Gonadal steroid induction of structural sex differences in the central nervous system. Annu Rev Neurosci $7: 413-442$.
Badley JE, Bishop GA, St John T, Frelinger JA (1988) A simple, rapid method for the purification of poly $\mathrm{A}^{+}$RNA. Biotechniques 6:114116.

Bradford MM (1976) A rapid and sensitive method for the quantitation of microgram quantities of protein utilizing the principle of protein-dye binding. Anal Biochem 72:248-254.

Breedlove SM (1992) Sexual differentiation of the brain and behavior. In: Behavioral endocrinology (Becker JB, Breedlove SM, Crews D, eds), pp 39-70. Cambridge, MA: MIT Press.

Carrer HF, Aoki A (1982) Ultrastructural changes in the hypothalamic ventromedial nucleus of ovariectomized rats after estrogen treatment. Brain Res 240:221-233.

Chen C, Okayama H (1987) High-efficiency transformation of mammalian cells by plasmid DNA. Mol Cell Biol 7:2745-2752.

Chung S, Pfaff D, Cohen R (1988) Estrogen-induced alterations in synaptic morphology in the midbrain central gray. Exp Brain Res 69: 522-530.

Clemens LG, Gladue BA, Coniglio LP (1978) Prenatal endogenous androgenic influences on masculine sexual behavior and genital morphology in male and female rats. Horm Behav 10:40-53.

Clough RW, Rodriguez-Sierra JF (1983) Synaptic changes in the hypothalamus of the prepubertal female rat administered estrogen. Am J Anat 167:205-214.

Corbier P (1985) Sexual differentiation of positive feedback: effect of hour of castration at birth on estradiol-induced luteinizing hormone secretion in immature male rats. Endocrinology 116:142-147.

Dermietzel R, Traub O, Hwang TK, Beyer E, Bennett MVL, Spray DC, Willecke K (1989) Differential expression of three gap junction pro- 
teins in developing and mature brain tissues. Proc Natl Acad Sci USA 86:10148-10152.

Diamond MC (1984) Age, sex, and environmental influences. In: Cerebral dominance: the biological foundations (Geschwind N, Galaburda AM, eds), pp 134-146. Cambridge, MA: Harvard UP.

Diamond MC, Dowling GA, Johnson RE (1981) Morphological cerebral cortical asymmetry in male and female rats. Exp Neurol 71: 261-268.

Diaz H, Lorenzo A, Carrer HF, Caceres A (1992) Time lapse study of neurite growth in hypothalamic dissociated neurons in culture: sex differences and estrogen effects. J Neurosci Res 33:266-281.

Döhler KD, Coquelin A, Davis F, Hines M, Shryne JE, Sickmöller PM, Jarzab B, Gorski RA (1986) Pre- and postnatal influence of an estrogen antagonist and an androgen antagonist on differentiation of the sexually dimorphic nucleus of the preoptic area in male and female rats. Neuroendocrinology 42:443-448.

Donis JA, Ventosa-Michelman M, Neve RL (1993) Comparison of expression of a series of mammalian vector promoters in the neuronal cell lines PC12 and HT4. Biotechniques 15:786-788.

Federoff HJ, Grabczyk E, Fishman MC (1988) Dual regulation of GAP-43 gene expression by nerve growth factor and glucocorticoids. J Biol Chem 263:19290-19295.

Ferreira A, Caceres A (1991) Estrogen-enhanced neurite outgrowth: evidence for a selective induction of Tau and stable microtubules. J Neurosci 11:392-400.

Fischette CT, Bigeon A, McEwen BS (1983) Sex differences in serotonin receptor binding. Science 222:333-335.

Frankfurt M, Gould E, Woolley CS, McEwen BS (1990) Gonadal steroids modify dendritic spine density in ventromedial hypothalamic neurons: a Golgi study in the adult rat. Neuroendocrinology 51:530535.

Goodman RL (1978) The site of the positive feedback of estradiol in the rat. Endocrinology 102:151-159.

Gorski RA (1984) Critical role for the medial preoptic area in the sexual differentiation of the brain. Prog Brain Res 61:129-146.

Gorski RA, Harlan RE, Jacobson CD, Shryne JE, Southam AM (1980) Evidence for the existence of a sexually dimorphic nucleus in the preoptic area in the rat. J Comp Neurol 193:529-539.

Gottardis MM, Jiang SY, Jeng MH, Jordan VC (1989) Inhibition of tamoxifen-stimulated growth of an MCF-7 tumor variant in athymic mice by novel steroidal antiestrogens. Cancer Res 49:4090-4093.

Gould E, Woolley CS, Frankfurt M, McEwen BS (1990) Gonadal steroids regulate dendritic spine density in hippocampal pyramidal cells in adulthood. J Neurosci 10:1286-1291.

Greene LA, Shooter EM (1980) The nerve growth factor: biochemistry, synthesis, and mechanism of action. Annu Rev Neurosci 3:353-402.

Greene LA, Tischler AS (1976) Establishment of a noradrenergic clonal line of rat adrenal pheochromocytoma cells which respond to nerve growth factor. Proc Natl Acad Sci USA 73:2424-2428.

Hammer RP, Jacobson CD (1984) Sex difference in dendritic development of the sexually dimorphic nucleus of the preoptic area in the rat. Int J Dev Neurosci 2:77-82.

Hatton GI, Yang QZ (1990) Activation of excitatory amino acid inputs to supraoptic neurons. I. Induced increases in dye-coupling in lactating, but not virgin or male rats. Brain Res 513:264-269.

Hatton GI, Yang QZ, Koran LE (1992) Effects of ovariectomy and estrogen replacement on dye coupling among rat supraoptic nucleus neurons. Brain Res 572:291-295.

Jacobs JR, Stevens JK (1986) Changes in the organization of the neuritic cytoskeleton during nerve growth factor-activated differentiation of PC12 cells: a serial electron microscopic study of the development and control of neurite shape. J Cell Biol 103:895-906.

Jacobson CD, Csernus VJ, Shryne JE, Gorski RA (1981) The influence of gonadectomy, androgen exposure, or a gonadal graft in the neonatal rat on the volume of the sexually dimorphic nucleus of the preoptic area. J Neurosci 1:1142-1147.

Jiang SY, Jordan VC (1992) Growth regulation of estrogen receptornegative breast cancer cells transfected with complementary DNA's for estrogen receptor. J Natl Cancer Inst 84:580-591.

Jones KJ, Chikaraishi DM, Harrington CA, McEwen BS, Pfaff DW (1986) In situ hybridization detection of estradiol-induced changes in ribosomal RNA levels in rat brain. Mol Brain Res 1:145-152.

Lauber AH, Mobbs CV, Muramatsu M, Pfaff DW (1991) Estrogen receptor messenger RNA expression in rat hypothalamus as a function of genetic sex and estrogen dose. Endocrinology 129:3180-3186.
I orenzo A, Diaz H, Carrer HF, Caceres A (1992) Amygdala neurons in vitro: neurite growth and effects of estradiol. J Neurosci Res 33: 418-435.

Luine VN, McEwen BS (1983) Sex differences in cholincrgic enzymes of diagonal band nuclei in rat preoptic area. Neuroendocrinology 36 : $475-482$.

Lustig RH, Mobbs CV, Bradlow HL, McEwen BS, Pfaff DW (1989) Differential regulation of estrogen receptor concentration in pituitary and preoptic area by estradiol and 16 $\alpha$-hydroxyestrone. Endocrinology 124:2701-2709.

Lustig RH, Sudol M, Pfaff DW, Federoff HJ (1991) Estrogenic regulation and sex dimorphism of growth-associated protein $43 \mathrm{kDa}$ (GAP43) messenger RNA in the rat. Mol Brain Res 11:125-132.

Lustig RH, Hua P, Wilson MC, Federoff HJ (1993) Ontogeny, sex dimorphism, and neonatal sex hormone determination of synapseassociated messenger RNA's in rat brain. Mol Brain Res 20:101-1 10.

Lye SJ, Nicholson BJ, Mascarenhas M, MacKenzie L, Petrocelli T (1993) Increased expression of connexin-43 in the rat myometrium during labor is associated with an increase in the plasma estrogen:progesterone ratio. Endocrinology 132:2380-2386.

Ma ZQ, Spreafico E, Pollio G, Santagati S, Conti E, Cattaneo E, Maggi A (1993) Activated estrogen receptor mediates growth arrest and differentiation of a neuroblastoma cell line. Proc Natl Acad Sci USA 90:3740-3744.

MacKenzie LW, Garfield RE (1985) Hormonal control of gap junctions in the myometrium. Am J Physiol 248:C296-C308.

MacLusky NJ, Naftolin F (1981) Sexual differentiation of the central nervous system. Science 211:1294-1303.

Matesic DF, Germak JA, Dupont F, Madhukar BV (1993) Immortalized hypothalamic luteinizing hormone-releasing hormone neurons express a connexin 26-like protein and display functional gap junction coupling assayed by fluorescence recovery after photobleaching. Neuroendocrinology 58:485-492.

Matsumoto A (1991) Synaptogenic action of sex steroids in developing and adult neuroendocrine brain. Psychoneuroendocrinology 16:2540.

Matsumoto A, Arai Y (1979) Synaptogenic effect of estrogen on the hypothalamic arcuate nucleus of the adult female rat. Cell Tissue Res 198:427-433.

Matsumoto A, Arai Y (1980) Sexual dimorphism in "wiring pattern" in the hypothalamic arcuate nucleus and its modification by neonatal hormonal environment. Brain Res 190:238-242.

Matsumoto A, Arai Y (1986) Male-female difference in synaptic organization in the ventromedial nucleus of the hypothalamus in rats. Neuroendocrinology 42:232-236.

Matsumoto A, Arai Y, Urano A, Hyodo S (1991) Cellular localization of gap junction mRNA in the neonatal rat brain. Neurosci Lett 124: 225-228.

McEwen BS (1983) Gonadal steroid influences on brain development and sexual differentiation. In: Reproductive physiology IV, pp 99123. Baltimore: University Park.

McEwen BS, Lieberburg I, Chaptal C, Krey LC (1977) Aromatization: important for sexual differentiation of the neonatal rat brain. Horm Behav 9:249-263.

McEwen BS, Lieberburg I, Chaptal C, Davis PG, Krey LC, MacLusky NJ, Roy EJ (1979) Attenuating the defeminization of the neonatal rat brain: mechanisms of action of cyproterone acetate, 1,4,6-androstatriene-3,17-dione and a synthetic progestin, R5020. Horm Behav 13:269-281.

McEwen BS, Bigeon $\Lambda$, Fischette CT, Luine VN, Parsons B, Rainbow TC (1984) Sex differences in programming of responses to estradiol in the brain. In: Sexual differentiation: basic and clinical aspects (Serio $M$, ed), pp 93-98. New York: Raven.

McShane S, Glaser L, Greer ER, Houtz J, Tong MF, Diamond MC (1988) Cortical asymmetry-a preliminary study: neurons-glia, malefemale. Exp Neurol 99:353-361.

Naus CCG, Feinstein D, Kidder GM (1988) Gap junctions during neocortical development: Northern blotting and immunocytochemistry. Soc Neurosci Abstr 14:414.6.

Naus CCG, Belliveau DJ, Bechberger JF (1990) Regional differences in connexin 32 and connexin 43 messenger RNAs in rat brain. Neurosci Lett 111:297-302.

Nishizuka M, Arai Y (1981) Organizational action of estrogen on synaptic pattern in the amygdala: implications for sexual differentiation of the brain. Brain Res 213:422-426. 
Parsons B, Rainbow TC, McEwen BS (1984) Organizational effects of testosterone via aromatization on feminine reproductive behavior and neural progestin receptors in rat brain. Endocrinology 115:14121417.

Peinado A, Yuste R, Katz LC (1993) Extensive dye coupling between rat neocortical neurons during the period of circuit formation. Neuron 10:103-114.

Pérez J, Luquín S, Naftolin F, Garcia-Segura LM (1993) The role of estradiol and progesterone in phased synaptic remodelling of the rat arcuate nucleus. Brain Res 608:38-44.

Petrocelli T, Lye SJ (1993) Regulation of transcripts encoding the myometrial gap junction protein, connexin-43, by estrogen and progesterone. Endocrinology 133:284-290.

Pozzo Miller LD, Aoki A (1991) Stereological analysis of the hypothalamic ventromedial nucleus. II. Hormone-induced changes in the synaptogenic pattern. Dev Brain Res 61:189-196.

Rainbow TC, Parsons B, McEwen BS (1982) Sex differences in rat brain oestrogen and progestin receptors. Nature 300:648-649.

Raisman G, Field PM (1973) Sexual dimorphism in the neuropil of the preoptic area of the rat and its dependence on neonatal androgen. Brain Res 54:1-29.

Rao A, Steward O (1991) Evidence that protein constituents of postsynaptic membrane specializations are locally synthesized: analysis of protcins synthcsized within synaptosomes. J Neurosci 11:28812895.

Romano GJ, Mobbs CV, Lauber AH, Howells RD, Pfaff DW (1990) Differential regulation of proenkephalin gene expression by estrogen in the ventromedial hypothalamus of male and female rats: 'implications for the molecular basis of a sexually differentiated behavior. Brain Res 536:63-68.

Segarra AC, McEwen BS (1991) Estrogen increases spine density in ventromedial hypothalamic neurons of peripubertal rats. Neuroendocrinology 54:365-372.

Shughrue PJ, Dorsa DM (1993) Estrogen modulates the growth-associated protein GAP-43 (neuromodulin) mRNA in the rat preoptic area and basal hypothalamus. Neuroendocrinology 57:439-447.

Shughrue PJ, Stumpf WE, MacLusky NJ, Zielinski JE, Hochberg RB (1990) Developmental changes in estrogen receptors in mouse cerebral cortex between birth and postweaning: studied by autoradiography with $11 \beta$-methoxy-16 $\alpha$-[25] ${ }^{125}$-iodoestradiol. Endocrinology 126: 1112-1124.

Steward O (1983) Alterations in polyribosomes associated with dendritic spines during the reinnervation of the dentate gyrus of the adult rat. J Neurosci 3:177-188.
Steward O, Falk PM (1991) Selective localization of polyribosomes beneath developing synapses: a quantitative analysis of the relationships between polyribosomes and developing synapses in the hippocampus and dentate gyrus. J Comp Neurol 314:545-557.

Steward O, Reeves TM (1988) Protein-synthetic machinery beneath postsynaptic sites on CNS neurons: association between polyribosomes and other organelles at the synaptic site. J Neurosci 8:176184.

Steward O, Davis L, Dotti C, Phillips LL, Rao A, Banker G (1988) Protein synthesis and processing in cytoplasmic microdomains beneath postsynaptic sites on CNS neurons. Mol Neurobiol 2:227-261.

Theodosis DT, Poulain DA (1989) Neuronal-glial and synaptic plasticity in the adult rat paraventricular nucleus. Brain Res 484:361366.

Toran-Allerand CD (1980) Sex steroids and the development of the newborn mouse hypothalamus and preoptic area in vitro. II. Morphological correlates and hormonal specificity. Brain Res 189:413427.

Toran-Allerand CD (1984) On the genesis of sexual differentiation of the central nervous system: morphogenetic consequences of steroidal exposure and the possible role of $\alpha$-fetoprotein. Prog Brain Res 61: 63-96.

Toran-Allerand CD, Gerlach JL, McEwen BS (1980) Autoradiographic localization of ${ }^{3} \mathrm{H}$-estradiol related to steroid responsiveness in cultures of the hypothalamus and preoptic area. Brain Res 184:517522.

Toran-Allerand CD, Hashimoto K, Greenough WT, Saltarelli M (1983) Sex steroids and the development of the newborn mouse hypothalamus and preoptic area in vitro. III. Effects of estrogen on dendritic differentiation. Dev Brain Kes 7:97-101.

Toran-Allerand CD, Miranda RC, Hochberg RB, MacLusky NJ (1992) Cellular variations in estrogen receptor mRNA translation in the developing brain: evidence from combined [ $\left.{ }^{125} \mathrm{I}\right]$ estrogen autoradiography and non-isotopic in situ hybridization histochemistry. Brain Res 576:25-41.

Woolley CS, McEwen BS (1992) Estradiol mediates fluctuation in hippocampal synapse density during the estrous cycle in the adult rat. J Neurosci 12:2549-2554.

Yamamoto T, Vukelic J, Hertzberg EL, Nagy JI (1992) Differential anatomical and cellular patterns of connexin 43 expression during postnatal development of rat brain. Dev Brain Res 66:165-180.

Yankner BA, Benowitz LI, Villa-Komaroff L, Neve RL (1990) Transfection of PC12 cells with the human GAP-43 gene: effects on neurite outgrowth and regeneration. Mol Brain Res 7:39-44. 